\title{
MATERIAL IMPACTS OF HIP-HOP ON URBAN DEVELOPMENT IN DAKAR: THE CASE OF EAUX SECOURS
}

\author{
Hilary HUNGERFORD \\ South Dakota State University, United States
}

\begin{abstract}
The creative city has emerged as a driving force in urban studies in both academic and urban planning realms. Increasingly, scholars are interrogating these ideas of the creative city and the creative class as to their political implications and applications to cities around the world. This paper focuses on the role of the artist in urban development through the case study of one hip-hop group from the Pikine neighborhood of Dakar. Pikine, a poor neighborhood on the outskirts of the city, is one of many neighborhoods prone to seasonal flooding. Where city government programs of flood alleviation failed to produce positive results, the hip-hop artists have succeeded to organize and work against flooding. The artists imagined a better urban future from the point of view of disadvantaged neighborhoods, and organized the community to make real, material impacts on the city.
\end{abstract}

Key Words: Dakar, hip-hop, creative city, seasonal flooding.

\section{Introduction}

The creative class has emerged as an important driver of urban and regional development around the world, but scholars continue to debate the roles and outcomes of these creative endeavors. Richard Florida brought the idea of creative cities and the creative class into the forefront in his work focused on the changing economic geographies of cities (Florida 2004, 2010, 2012, Florida et al. 2008). In these works, Florida argued that the creative class - the segment of the population whose livelihood depend on personal creativity as part of the knowledge and information based economy - tends to cluster in specific areas, and that these clustering groups positively impact regional development and urban economic growth (Boschma and Fritsch 2009, Storper and Scott 2009, Booyens 2012). Increasingly, cities in the United States and Europe actively promote "creative placemaking" through public programs, private initiatives, and stakeholder participation (Markusen and Gadwa 2010). Some scholars argue that these creative city developments are merely a different repackaging of neoliberal economic models of urban growth and do not represent a substantial shift in development (Peck 2005, Krätke 2010). Moreover, in the creative cities literature the political power of artists themselves are often unfairly reduced to consumption and purchasing power (Markusen 2006).

More broadly, a shift to focus on the creative class assumes a shift of power dynamics in urban development from state-centered authority to a more mosaic amalgam of power comprised of the state, private interests, public participation, personal preferences, non-governmental interest groups, and increasingly connections across the globe (Light and Young 2010). How these power dynamics align and manifest in different regions of the world, and the corresponding role of the creative class, remains an important area of research. How power dynamics and the creative class affects urban redevelopment in cities that do not share the Fordist histories of American and European cities is an important emerging theme in scholarship (Visser 2013). Evidence from post-socialist cities suggests that government-led changes in the urban cultural landscape have not been enough to transform particular places, and the socialist legacy lingers in liminal and forgotten spaces around the city (Light and Young 
2010). Also, post-socialist cities have experienced inner-city redevelopment that is often associated with the creative class in the United States, but in Central and East Europe theses redevelopments have been driven by liberalization of the housing markets and local government policies (Kovács et al. 2013). In cities in the developing world, the role of the creative class and cultural industries are often overlooked in favor of scholarship focused on urban developmentalist problems and paradigms (Myers 2005).

In this paper, I focus on the role of cultural industries and the creative class in cities in Africa through a case study of a hip-hop group from Dakar, Senegal - Eaux Secours - and their campaign to prevent local flooding in precarious neighborhoods in Dakar. The paper will first examine hip-hop in Dakar in particular as an example of a creative class and cultural industry. Next, I will present an overview of the controversial Plan Jaxay, an urban redevelopment program to prevent seasonal flooding in Dakar. I then present a case-study on the response of Eaux Secours to Plan Jaxay, and highlight the contribution of artists in responding to urban problems. Finally, I will outline how the case from Dakar, Senegal helps shed light on a different kind of creative class emerging in cities around the world.

\section{Materials and Methods}

This study uses qualitative methods of observation, interviews, and content analysis to explore the contribution of artists in urban development in Dakar. Observations and interviews took place in the Pikine neighborhood of Dakar in May 2013. The particular hip-hop group Eaux Secours came to my attention through their participation in the Dakar youth hip-hop movement (detailed below). I interviewed the three primary group members, and also went on a neighborhood walking tour with the group to affected areas. Walking and pedestrian geographies with research participants has emerged within cultural geography studies as a useful methodology with which to gain insight into how people understand their physical and social geographic landscapes (Anderson 2004). In these walking and talking tours, much of the data that underpins this study was collected. Pictures were taken along the tour, as well as field notes, and detailed notes were then written once the tour came to an end. Songs and music videos from Eaux Secours are the data for the content analysis. Most songs are performed in Wolof, a principal language in Senegal, and selected bits were translated for the author into French. Music videos are available on YouTube, and are also in the Wolof language. Social networking sites, especially Facebook, are also important platforms for Eaux Secours, and are thus used as data points in this study. Information on the Plan Jaxaay was collected from national and international news sources, as well as student projects from Cheikh Anta Diop University in Dakar.

\section{Results and Discussion}

Before presenting the case study of hip-hop and neighborhood flooding, a more detailed context of both Dakar and the role of hip-hop in Dakar urban social movements will be presented.

\section{The Setting: Dakar, Senegal}

Dakar is home to nearly one in every five people in Senegal (World Factbook 2013), and one of the premier cosmopolitan urban centers on the continent of Africa. In 2009, the population of Dakar was estimated to be nearly three million people, with approximately $60 \%$ of the three million inhabitants under the age of 25 (World Factbook 2013). Urban centers in Senegal are growing at a faster rate than rural areas as people leave the countryside in search of better opportunities in cities (UN 2013). Though ranked 154 (out of 178) on the United Nation's 
Human Development Index (UN 2013), Senegal has experienced political stability with no successful coup d'états since independence from France in 1960 (Resnick 2013). In 2005, the United Nations estimated that gross national income per person was just over $\$ 1600$ (World Factbook 2013), with increasing rates of income inequality. Water and electricity infrastructure coverage rates in Dakar are estimated to be near 90\% (World Factbook 2013), but access to these networked services proves to be more difficult in certain zones.

\section{Plan Jaxaay}

Many neighborhoods in Dakar experience seasonal low-level flooding associated with the rainy season, lasting from about June to September in a normal year. It is common for roads to become impassible because of water levels as rains make the already challenging system of unpaved roads more precarious. The densely populated, and often unplanned, neighborhoods on the outside of central Dakar are particularly prone to seasonal flooding (Douglas et al. 2008). Pikine is one such neighborhood. The Pikine neighborhood was settled in the early 1950s as part of the urban restructuring of Dakar that involved displacing dense neighborhoods in the city center to peripheral locations (Diop 2010). Parts of the vast neighborhood are planned, but an influx of rural populations seeking refuge from drought conditions in the 1970s settled in the neighborhood in unplanned settlements. Many of these unplanned settlements occupied what were at the time dry ephemeral drainage channels (Tschakert et al. 2010). When rain patterns increased, these drainage channels became areas prone to flooding, both because of their natural physical geographic context and the changes in land surface conditions brought on by settlement. Moreover, the water table remained high in Pikine, though on the surface it is undetectable (Diop 2013).

Heavy rains in 2005 brought the problem of seasonal flooding in Dakar into the forefront, as neighborhoods around the city were inundated with both storm water runoff and household wastewater (IRIN 2006). At the peak of the crises, twenty thousand people were displaced from their homes and forced to find shelter with families, friends, and on city streets (IRIN 2006). Photographs of devastated neighborhoods and houses building water barriers out of trash were all over international press (IRIN 2006). In these flooded neighborhoods, the population suffered from increased rates of malaria, gastrointestinal illness, and even cholera.

In response, then President Wade and his urban planning agency developed the Plan Jaxaay. The Plan Jaxaay, which in the Wolof language means Bird Flies Higher Plan (IRIN 2006), relied on two central features: relocating populations from flood-prone areas and channeling storm water into catchment basins within neighborhoods themselves. The relocation programs were voluntary programs and involved populations moving from inundated neighborhoods to statebuilt planned developments an hour outside of Dakar (Koenig 2011). The new planned neighborhoods under the Plan Jaxaay have uniform, 2 to 3 bedroom houses which the government subsidized and then make available at reduced cost, provided the household agrees to 20-year loan agreements (IRIN 2006). Some displacements have occurred in Pikine, but many households are reticent to leave because of the far distance of the new communities and the lack of trust that they will indeed get what they have been promised (Nettali 2008). Some residents of the new communities also report irregularities in electricity and other urban services (Nettali 2008).

Catchment basins have been constructed in five neighborhoods across Dakar in attempts to alleviate the complete inundation of neighborhoods during the rainy season (Diop 2010). In Pikine, one such basin was constructed in 2007 (Diop 2010). First, households occupying the land in which the basin was planned were evacuated, and channels were constructed along 
secondary and tertiary roads to divert water into the basin. A pump was installed at the basin, and water was to be pumped out via a complex network of pipes either into rural peripheral lake systems or diverted into coastal Atlantic delta locations. The catchment basin plan worked as planned, and alleviated some of the worst flooding, but was a temporary solution to a persistent problem (IRIN 2006). The basin size was not adequate to catch even the majority of run-off, and the intermittent pumping of water to further locations exacerbated the basin capacity problems. Residents reported a complete stop in water pumping, which means the basin has become a permanent feature in the neighborhood (Fig. 1). Officially, the Plan Jaxaay has ended its first planned phase, and neighborhoods like Pikine are waiting to see what manifests as future projects. As of now, little discussion has taken place, and neighborhoods are left to deal with the consequences of an urban development experiment.

Dangers of the basin have proven to be just as formidable as dangers posed by seasonal

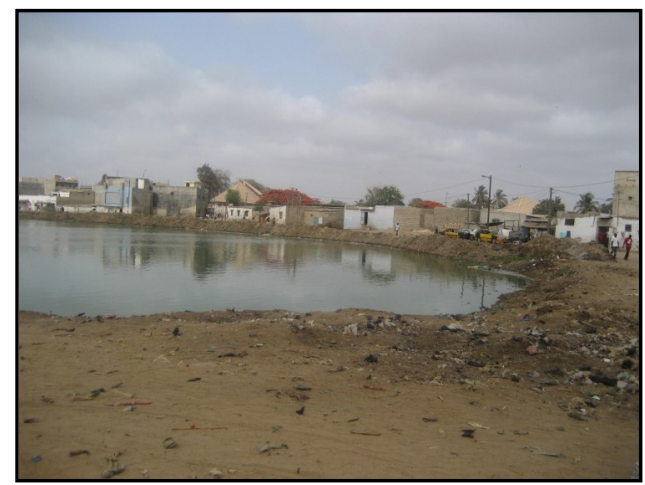

Fig. 1 - Catchment basin from Plan Jaxaay development plan in the Pikine neighborhood

May 2013. Photograph by the author.

flooding. From 2007 to 2013, nine children had drowned in the basin because of lack of fence or buffer zone between the basin and the surrounding areas. The basin has also become an unofficial site of wastewater disposal of neighborhood residents, and the water within discolored, brackish, and foul smelling. Trash, especially plastic rubbish, surrounds the edges of the basin, and can be found in nearby soil up to a meter deep. Not only is the basin unappealing to visual and olfactory senses, but it harbors within it vectors of illness and disease, and is an especially conducive environment for mosquito breeding. Residents near the catchment basins report increased rates of malaria and gastrointestinal illnesses. Now that water is only rarely pumped out, seasonal flooding is not relieved, but also the catchment basin risks to spill out into the neighborhood in the event of an intense rainfall event. What was supposed to relieve flooding stress has only seemed to create more. The community in Pikine has started to mobilize and search for solutions to persistent dangers posed by flooding, and Eaux Secours is an important part of this effort.

\section{The role of hip-hop in Dakar}

Hip-hop in Dakar is more than just an art or music expression, but is a practice deeply intertwined in the political performance and production of space of Dakar's youth (Pieterse 2010, Clark 2012, Fredericks 2013). There are thousands of hip-hop groups in Dakar today, and the poor outskirts of the city (the banlieue) house an overwhelming majority of these groups (Fredericks 2013). Hip-hop in Dakar takes inspiration from American rap music and movements from the 1980s, which were a way for disenfranchised urban, black youth in the United States to voice societal grievances and imagine a different future. The 1980s in Dakar was marked by political volatility and numerous massive youth strikes occurred in Dakar later in 
the decade (Herson 2011). In 1989 particularly, school strikes occurred with such frequency that the year was declared void, and the youth of Dakar found themselves feeling frustrated and with nothing to do but exchange ideas and envision a different reality (Ntarangwi 2010).

Hip-hop continued to grow in importance for youth culture and political mobilization throughout the 1990s, spurred by the increasing globalization around the world driven by economic development and technological innovation (Ntarangwi 2010, Beach and Sernhede 2012). At first, hip-hop in Dakar imitated American styles in terms of musical underpinnings and lyric construction, but it soon became something uniquely Senegalese because of its deep roots in neighborhoods and active discourse of transforming the city into a more just and equal place (Fredericks 2013). In the midst of rapid globalization in urban Senegal, many youth in the poor, densely populated neighborhoods like Pikine found themselves at the bottom of a social order that was transforming life around the world. They saw the consequences of this inequality in the characteristics of their neighborhoods, such as inaccessibility to water and sanitation, high unemployment, difficulty attaining education, and inaccessibility of social mobility (Ntarangwi 2010). Artists began to mobilize and organize to change neighborhood practices, and reimagined a city with the poor neighborhoods as the core of urban life. Hip-hop artists did more than represent their neighborhoods through music; they used music to create their neighborhoods, and this legacy continues today (Fredericks 2013).

The power of this youth hip-hop movement in Dakar came to forefront in 2011, as two young rappers created the Y'en a Marre (which means "fed up" in Wolof) movement (Resnick 2013). The early focal point for the Y'en a Marre movement was the presidential elections in which President Wade was running for an unconstitutional third term presidency (Fredericks 2013). The Y'en a Marre movement organized youth to protest government inadequacies, succeeded in registering thousands of youth across the country to vote, and ultimately helped to defeat the incumbent Wade in the following year's election (Resnick 2013). These successes by the Y'en a Marre movement inspired hip-hop groups across the country, and particularly in the poor neighborhoods of Dakar, to translate their music into action. Eaux Secours in one such hip-hop group that took this call to action seriously.

\section{The case of Eaux Secours}

The group Eaux Secours (which means "water emergency" in French) was created when three friends from the Pikine neighborhood came together after the flooding season in 2012. Once again houses across the neighborhood flooded and residents waded for months through water to city streets. During the dry season, the flood line is visible on the exterior walls of houses, a constant reminder of what occurred and what will come again once the rains start. At its worst, water was knee-deep and people barricaded their houses with discarded trash to try to protect against total devastation. The three founders of the group experienced this flooding in their own households, as well as that of their family and friends. They used the same political platform through which other young people in Dakar have made their voices heard: hip-hop. Their first album was released in April 2013, and the first music video released on YouTube a few months later.

When initially asked to describe their group objectives, they responded that their primary objective was "la lute contre les inondations" - the fight against flooding. Puzzled, I asked how you stop flooding, a process and problem more ascribed to natural phenomenon and disasters. They explained that flooding is not only a natural phenomenon, but is also socially produced. They described that only certain neighborhoods in Dakar flood, and that flooding occurs disproportionately in poor neighborhoods like Pikine. They attribute this increased risk of 
flooding in Pikine not necessarily to physical geographic contexts of the neighborhood (Diop 2013), but to social processes of exclusion and uneven development within Dakar. This perception of the flooding risk (Fatti and Patel 2012) drives their crafting of song lyrics, and also results in local material improvements to the city. These material improvements of Eaux Secours, and of Y'en a Marre in general (Fredericks 2013), is an important way that artists shape and transform the city of Dakar. These material improvements are also highlighted in their most recent music video.

The music video shows members of the group singing against the backdrop of flooded neighborhoods. Other than group members, most of the other people featured are children, representing the importance of flooding as a public health risk to the most vulnerable of the neighborhood's populations. Also shown are standing water, small ponds, and catchment basins that have experienced eutrophication, or the dense growth of algae and small plant life because of the increased nutrient load, presumably from human waste occurring nearby. Children play next to these eutrophic ponds, a visual rhetorical move to which the viewer responds with disgust. Also shown on the video are the remnants of houses that were evacuated, though not totally destroyed, under the Plan Jaxaay. These house ruins are now combinations of falling walls, eutrophic standing water, and trash. Trash has been a major problem associated with the Plan Jaxaay, as people use catchment basins as disposal points for used household water and trash because of the sporadic nature of urban service provision in the neighborhood. Concurrent with these images in the video is the song, Zero Mbeund, in which the group criticizes the government for their failed urban planning scheme and what they see as the general neglect of poor populations.

The final scenes of the video show group members and other young men building a trench and retaining wall around the largest pond, picking out large trash pieces, and wading through the green, brackish water along with the word "solution" written across the screen. Eaux Secours is an active, transformative agent in the city through political and material "placemaking" (Fredericks 2013). They plead for government action, but instead of just raising awareness and calling attention, they engage in the search for local solutions to complex urban problems. Their practice is a kind of vigilante, informal urban development, intervening where the government has demonstrated inadequacy in resolving problems. Through the political engagements of their music and the material engagements of their redevelopment projects, Eaux Secours claims their "rights and rewards of the city through occupying its physical space and the space of public dialogue" (Fredericks 2013: 10). By showing the group engaging in the dirty work of improving the city, they show the potential power of the artist to not only intervene politically, but to make positive material changes in the urban fabric.

In Dakar, the impacts of Eaux Secours material work is limited to one or two catchment basin improvements. The magnitude of the problem of seasonal flooding in these neighborhoods cannot be solved by small projects, but rather requires large-scale intervention, the kind that is likely only possible through government projects. These larger projects, however, are misguided, inadequate, and intermittent. Eaux Secours acknowledges that the problem is massive and that their interventions are limited, but recognize action as the only option until larger solutions arrive. Through their actions, moreover, they endeavor to call further attention to the plight of poor neighborhoods, which will then warrant action by city planning institutions.

\section{Conclusions}

The "creative place-making" movement that undergirds contemporary urban development schemes in the United States and Europe focuses not on the political power of the artist, but 
rather the entrepreneurial aspect of cities as they attempt to engage with urbanites and the knowledge economy. The creative city becomes a tool of the powerful and the elite to re-shape urban landscapes into spaces of commerce and opportunity. This kind of creative city, where creativity comes from above and is projected onto unsuspecting places, stands in stark contrast to the political movements of art rooted deeply in place that take place around the world.

In Dakar, the defining social and political movement of the past three years has been the power of the artist to effect change. Artists in Dakar actively and consciously produce urban space, particularly in poor neighborhoods on the outskirts of the city. Hip-hop movements in Dakar do more than change social and political spaces of the city, they also intervene in the material constitution of their neighborhoods, neighborhoods that are on the physical, social, and political periphery of contemporary Dakar. They alter physical spaces to align with their political ideals of equality, democracy, and the importance of youth.

The example of Eaux Secours and hip-hop artists in Dakar prompts us to reconsider the position and power of the artist in the city. Is the artist privileged only as part of a larger creative class, a class characterized by high education and income that is described by urban planners? What about the artist who speaks to the urban condition from the vantage point of the dispossessed, are not their voices also useful in imagining the future of cities? The answer, perhaps, is an issue of positionality. Eaux Secours speaks from their position of youth in a poor, disenfranchised neighborhood of Dakar. They are not speaking about problems or ways to improve the city, as they urban planners in the Plan Jaxaay. Rather, these artists speak from these places that need improvement. These real, lived experiences of people in marginal places are perhaps one of the most useful tools to consider in imagining better urban futures.

\section{References}

BEACH, D., SERNHEDE, O. (2012), Learning processes and social mobilization in a Swedish metropolitan hip-hop collective, Urban Education, 47, 5, pp. 939-958.

BOOYENS, I. (2012), Creative industries, inequality and social development: developments, impacts and challenges in Cape Town, Urban Forum, 23, 1, pp. 43-60.

BOSCHMA, R., A., FRITSCH, M. (2009), Creative class and regional growth: Empirical evidence from seven European countries, Economic Geography, 85, 4, pp. 391-423.

CLARK, M., K. (2012), Hip Hop as Social Commentary in Accra and Dar es Salaam, African Studies Quarterly, 13, 3, pp. 23- 46.

DIOP, A., K. (2010), La problématique de l'assainissement dans le département de Pikine (Sénégal), (Master of Arts thesis), Geography Department, Université Cheikh Anta Diop de Dakar.

DIOP, S., H. (2013), GIS-Based Flood Analysis for Adequate Flood Mitigation in an Unplanned Urban Area; The Case of Pikine Dagoudane in Dakar County, Senegal, (Master of Arts thesis), Geography Department, Western Michigan University.

DOUGLAS, I., ALAM, K., MAGHENDA, M., A., MCDONNELL, Y., MCLEAN, L., CAMPBELL, J. (2008), Unjust waters: climate change, flooding and the urban poor in Africa, Environment and Urbanization, 20, 1, pp. 187-205.

FATTI, C., E., PATEL, Z. (2012), Perceptions and responses to urban flood risk: Implications for climate governance in the South, Applied Geography, 36, pp. 13-22.

FLORIDA, R. (2004), Cities and the creative class, Routledge, New York.

FLORIDA, R. (2010), The flight of the creative class: The new global competition for talent, Harper Collins, New York.

FLORIDA, R. (2012), The Rise of the Creative Class: Revisited, Basic Books, New York. 
FLORIDA, R., MELLANDER, C., STOLARICK, K. (2008), Inside the black box of regional development - human capital, the creative class and tolerance, Journal of economic geography, 8, 5, pp. 615-649.

FREDERICKS, R. (2013), "The Old Man is Dead": Hip Hop and the Arts of Citizenship of Senegalese Youth, Antipode, pre-published online 29 July 2013, Doi:10.1111/anti.12036, pp.1-19.

HERSON, B. (2011), A Historical Analysis of Hip-Hop's Influence in Dakar from 19842000, American Behavioral Scientist, 55, 1, pp. 24-35.

KOENIG, D. (2011), Multiple Actors and Contested Terrains Strategies of Pro-poor Action in Contemporary Urban Restructuring, Journal of Developing Societies, 27, 3-4, pp. 327353.

KOVÁCS, Z., WIESSNER, R., ZISCHNER, R. (2013), Urban renewal in the inner city of Budapest: Gentrification from a post-socialist perspective, Urban Studies, 50, 1, pp. 22-38.

KRÄTKE, S. (2010), 'Creative Cities' and the Rise of the Dealer Class: A Critique of Richard Florida's Approach to Urban Theory, International Journal of Urban and Regional Research, 34, 4, pp. 835-853.

LIGHT, D., YOUNG, C. (2010), Reconfiguring socialist urban landscapes: the 'left-over' spaces of state-socialism in Bucharest, Human Geographies, 4,1, pp. 5-16.

MARKUSEN, A. (2006), Urban development and the politics of a creative class: evidence from a study of artists, Environment and planning A, 38, 10, pp. 1921-1940.

MARKUSEN, A., GADWA, A. (2010), Arts and culture in urban or regional planning: $A$ review and research agenda, Journal of Planning Education and Research, 29, 3, pp. 379-391. MYERS, G. A. (2005), Place and humanistic African cultural geography: a Tanzanian case, Journal of Cultural Geography, 22, 2, pp. 1-26.

NTARANGWI, M. (2010), African Hip Hop and Politics of Change in an Era of Rapid Globalization, History Compass, 8, 12, pp.1316-1327.

PECK, J. (2005), Struggling with the creative class. International Journal of Urban and Regional Research, 29, 4, pp. 740-770.

PIETERSE, E. (2010), Hip-hop cultures and political agency in Brazil and South Africa, Social Dynamics, 36, 2, pp. 428-447.

RESNICK, D. (2013), Continuity and change in Senegalese party politics: Lessons from the 2012 elections, African Affairs, 112, 449, pp. 623-645.

STORPER, M., SCOTT, A. J. (2009), Rethinking human capital, creativity and urban growth, Journal of Economic Geography, 9, 2, pp. 147-167.

TSCHAKERT, P., SAGOE, R., OFORI-DARKO, G., CODJOE, S.. N. (2010), Floods in the Sahel: an analysis of anomalies, memory, and anticipatory learning, Climatic Change, 1033 -4 , pp. 471-502.

UNITED NATIONS (2013), Human Development Report 2013. The rise of the South: human progress in a diverse world, United Nations Development Program, New York.

VISSER, G. (2013), The Film Industry and South African Urban Change, Urban Forum, pre-published online 4 August 2013, DOI:10.1007/s12132-013-9203-3.

WORLD FACTBOOK (2013), Washington, DC: Central Intelligence Agency, online at: https://www.cia.gov/library/publications/the-world-factbook/.

Initial submission: 14.08.2013

Revised submission: 07.10 .2013

Final acceptance: 29.11.2013

Correspondence: South Dakota State University, Department of Geography, Wecota Hall (SWC) 109, Box:506, Brookings, SD 57007, Unite States.

E-mail: hilary.hungerford@sdstate.edu 